\title{
Implementasi Forward Chaining untuk Identifikasi Dini Penyakit Akibat Ketergantungan Narkoba Jenis Ganja
}

\author{
${ }^{1}$ Ayu Mira Yunita, ${ }^{2}$ Andrianto, H.W, ${ }^{3}$ Susilawati \\ ${ }^{1}$ Jurusan Sistem Informasi, Fakultas Informatika dan Komputer -Universitas Mathla'ul Anwar \\ 'ayumirayunita@gmail.com, ${ }^{2}$ andri_htilyahoo.co.id, ${ }^{3}$ ssusilawati7971@yahoo.co.id
}

\begin{abstract}
Abstrak - Narkotika adalah singkatan dari narkotika, psikotropika, dan bahan adiktif lainnya. Zat aktif dalam obat dapat bereaksi negatif terhadap tubuh. Efek terburuk akibat kandungan kimia obat adalah perubahan psikologis dan kematian. Salah satu jenis narkotika yang sangat berbahaya adalah ganja, ganja berasal dari tanaman canabis sativa yang berwarna hijau jika masih segar dan menjadi kecoklatan saat dikeringkan. Pengaruh ganja pada pengguna adalah membuat tubuh pemakai rileks, merasa nyaman, kegembiraan yang berlebihan (euporia), mengalami sensasi keliru dalam penciuman dan penglihatan pendengaran yang disebut halusinasi. Tidak hanya menimbulkan kecanduan, akibat penyalahgunaan narkoba ganja ternyata berdampak pada identifikasi berbagai penyakit terhadap narkoba. Penelitian ini bertujuan untuk mengidentifikasi penyakit awal yang disebabkan oleh penyalahgunaan narkoba jenis ganja. Proses inferensi untuk mengidentifikasi jenis penyakit menggunakan pendekatan berbasis aturan dengan teknik perangkaian ke depan untuk menentukan hipotesis (jenis penyakit) karena kecanduan
\end{abstract} penyalahgunaan narkoba.

Keywords: drugs, diagnostics, expert systems, forward chaining

\section{PENDAHULUAN}

Narkoba merupakan singkatan dari Narkotika, Psikotropika dan Bahan adiktif lainnya.Zat aktif dalam narkoba dapat bereaksi negatif pada tubuh. Akibat terparah karena kandungan kimia narkoba adalah adanya perubahan kejiwaan serta kematian.Hingga pada saat ini pemakai narkoba semakin meningkat, dan menjadi pembunuh nomor satu di dunia. Tidak tanggung- tanggung dari usia dewasa sampai anak sekolah dasar. Salah satu jenis narkotika yang sangat berbahaya yaitu ganja, ganja berasal dari tanaman canabis sativa yang berwarna hijau bila masih segar dan menjadi kecoklatan bila di keringkan. Pengaruh ganja pada pemakai yaitu menjadikan tubuh pemakai merasa rileks, merasa nyaman, rasa gembira (euporia) yang berlebihan, mengalami sensasi palsu dalam penglihatan penciuman dan pendengaran yang disebut halusinasi.

Penyalahgunaan narkoba tidak hanya menyebabkan kecanduan, akan tetapi juga mengakibatkan berbagai penyakit yang bisa menyebabkan kematian. Hingga tahun 2017 angka kematian akibat penyakit yang disebabkan penyalahgunaan narkoba terus meningkat, sebagian besar korbannya adalah remaja.Salah satu faktor utama permasalahnya yaitu rata-rata remaja yang menggunakan narkoba tidak mengetahui secara pasti penyakit apa yang ditimbulkan oleh narkoba khususnya jenis ganja serta solusi atau saran untuk penyembuhan penyakit tersebut. Penyakit akibat penyalahgunaan narkoba.

Memang sulit untuk dikenali. Penyebabnya adalah gejala yang terlihat antara pengaruh kecanduan dengan terserang penyakit akibat kecanduan sering sulit dibedakan. Inilah yang menjadikan kesulitan tersendiri untuk memberikan pertolongan kepada para pecandu narkoba untuk pencegahan penyakit yang dideritanya. Kesulitan ini juga yang dihadapi oleh Badan Narkotika Nasional Provinsi Banten.

Badan narkotika nasional (BNN) provinsi Banten salah satu badan penanganan narkotika di wilayah Banten.Keterbatasan dokter spesialis pada kantor BNN menjadi kesulitian tersendiri untuk mengidentifikasi penyakit yang diakibatkan kecanduan narkoba. Saat ini ketersediaan dokter hanya sebatas dokter umum yang bertugas untuk memberikan informasi mengenai penyakit yang bisa di derita para pasien. Informasi biasanya disampaikan ketika sedang menjalankan rehabilitas. Tidak hanya keterbatasan dokter spesialis yang ada di BNN, keterbatasan waktu kerja untuk dokter umum 
yang bertugas di BNN juga menjadi permasalahan lainnya.Saat ini, BBN Provinsi Banten juga belum memiliki dokter spesialis yang bertugas khusus dan menetap disana, sehingga jika terjadi kasus yang menimpa pecandu narkoba di tempat rehabilitasi sering terjadi keterlambatan dalam pelayanan kepada para pasien. Dibutuhkan solusi alternatif untuk mengatasi permasalahan keterbatasan dokter spesialis penyakit yang diakibatkan kecanduan penyalahgunaan narkoba. Ada banyak pendekatan alternatif yang bisa dilakukan salah satunya menggunakan teknologi informasi melalui konsep sistem pakar.

Sistem pakar sendiri merupakan aplikasi yang dikembangkan sebagai upaya untuk memindahkan kemampuan pakar ke dalam sebuah aplikasi sehingga mampu mengatasi keterbatasan pakar pada bidang-bidang tertentu. Pada penelitian ini akan dikembangkan sistem pakar untuk mengidentifikasi jenis penyakit yang diakibatkan penyalahgunaan narkoba bagi pecandunya. Pendekatan rule based dengan teknik forward chaining akan digunakan sebagai metode inferensi dalam mendiagnosa jenis penyakit pada pecandu narkoba.Penggunaan rule based digunakan pada proses pencarian jenis penyakit (inferensi) ketika pengguna sistem pakar memasukan gejala-gejala yang dialaminya saat berkonsultasi melalui antarmuka. Output sistem pakar tidak hanya menginformasikan jenis penyakit yang diderita oleh pecandu narkoba, akan tetapi juga disertai informasi tambahan berupa pencegahan dini dan jenis obat alternatif yang bisa digunakan jika pecandu narkoba terindikasi menderita penyakit tertentu. Sistem pakar yang dikembangkan diharapkan memberi kontribusi positif bagi BNN Provinsi Banten untuk mengatasi keterbatasan dokter spesialis..

\section{A. Sistem Pakar}

Menurut Turban (2005), Sistem pakar (expert system) adalah sistem yang berusaha mengadopsi pengetahuan manusia ke komputer yang dirancang untuk menyelesaikan masalah seperti layaknya seorang pakar, keahlian dipindahkan dari pakar ke suatu komputer. Pengetahuan ini kemudian disimpan di dalam komputer.Pada saat pengguna menjalankan komputer untuk mendapatkan informasi, sistem pakar menanyakan fakta-fakta dan dapat membuat penalaran (inferensi) dan sampai pada suatu kesimpulan.Kemudian, sistem pakar memberikan penjelasan (memberikan kesimpulan atas hasil konsultasi yang telah dilakukan sebelumnya).

\section{B. Metode Forward Chaining}

Metode Forward Chaining adalah metode pencarian atau teknik pelacakan ke depan yang dimulai dengan informasi yang ada dan penggabungan rule untuk menghasilkan suatu kesimpulan atau tujuan (jurnal informatika mulawarman juni 2010) Pelacakan maju ini sangat baik jika bekerja dengan permasalahan yang dimulai dengan rekaman informasi awal dan ingin dicapai penyelesaian akhir, karena seluruh proses akandikerjakan secara berurutan maju.

Forward Chaining secara umum untuk menghasilkan sebuah goal. Forward chaining merupakan metode inferensi yang melakukan penalaran dari suatu masalah kepada solusinya. Jika klausa premis sesuai dengan situasi (bernilai TRUE), maka proses akan menyatakan konklusi. Forward Chaining adalah data-driven karena inferensi dimulai dengan informasi yang tersedia dan baru konklusi diperoleh. Jika suatu aplikasi menghasilkan tree yang lebar dan tidak dalam, maka gunakan Forward Chaining.Tipe sistem yang dapat dicari dengan Forward Chaining.

Sistem yang dipersentasikan dengan satu atau beberapa kondisi.Untuk setiap kondisi, sistem mecari rule-rule dalam knowledge base untuk rule-rule yang berkorespondensi dengan kondisi dalam bagian IF setiap rule dapat menghasilkan kondisi baru dari konklusi yangdiminta pada bagian THEN. Kondisi baru iniditambahkan ke kondisi lain yang sudah ada.

Setiap kondisi yang ditambahkan ke sistem akan diproses. Jika ditemui suatu kondisi baru dari konklusi yang diminta, sistem akan kembali ke langkah 2 dan mencari rule-rule dalam knowledge base kembali. Jika tidak ada konklusi baru, sesi ini berakhir.

\section{Narkoba}

Narkoba adalah singkatan dari narkotika dan obat/bahan berbahaya. Selain "narkoba", istilah lain yang diperkenalkan khususnya oleh Kementerian Kesehatan Republik Indonesia adalah Napza yang merupakan singkatan dari narkotika, psikotropika, dan zat adiktif. Semua istilah ini, baik "narkoba" ataupun "napza", mengacu pada kelompok senyawa yang umumnya memiliki risiko kecanduan bagi penggunanya.

Menurut pakar kesehatan, narkoba sebenarnya adalah senyawa-senyawa psikotropika yang biasa dipakai untuk membius 
pasien saat hendak dioperasi atau obat-obatan untuk penyakit tertentu.Namun kini persepsi itu disalahartikan akibat pemakaian di luar peruntukan dan dosis yang semestinya (Tim Kreatif BNN, 2007).

\section{Metodologi Penelitian}

Penelitian ini diawali dengan identifikasi permasalahan yang terjadi di lapangan kemudian dilanjutkan dengan pengumpulan data pendukung. Data pendung berupa informasi penyakit yang biasa diderita oleh pecandu narkoba beserta gejala-gejala yang ditimbulkannya. Tahap selanjutnya adalah mengekstrak data yang sudah dikumpulkan ke dalam aturan-aturan $I F$. Selanjutnya aturan yang sudah terbentuk digunakan untuk diujikan kepada sample pecandu narkoba untuk diidentifikasi jenis penyakit yang dialaminya.

\section{Hasil dan Pembahasan}

Untuk melakukan penelusuran jenis penyakit akibat kecanduan narkoba menggunakan metode forward chaining, maka disusun skenario pengujian terdiri dari beberapa langkah sebagai berikut:

Langkah 1: Mengajukan pertanyaan kepada pasien

Langkah 2: Menampung inpitan dari user sebagai faktayang diketahui pada short term memory yang di simpan pada tiap variable pertanyaan yang diajukan.

Langkah 3: Memeriksa rule berdasarkan fakta pada short term memeory

Langkah 4: Jika rule ditemukan maka konklusi rule ditampung pada short term memory,apabila ada fakta baru maka langkah satu sampai empat diulang, jika rule tidak ditemukan maka berikan default output.

Langkah 5: Memberikan solusi

Dengan ketentuan bahwa apabila pada bagian premis ( jika ) terpenuhi, maka bagian konklusi (maka) juga akan bernilai benar. Tabel 1 merupakan aturan yang digunakan untuk mengidentifikasi penyakit akibat kecanduan narkoba. Sedangkan aturan solusi alterinatif untuk setiap penyakit yang teridentifikasi seperti diperlihatkan pada Tabel 2.

Tabel 1. Aturan untuk Gejala Penyakit

\begin{tabular}{ll}
\hline No & Gejala Penyakit \\
\hline \hline 1. & IF air kemih yang berubah warna \\
& menjadi seperti air teh AND hilangnya \\
& selera makan AND rasa mual yang \\
& terjadi dengan frekuensi yang cukup
\end{tabular}

sering AND perubahan pada feses menjadi pucat AND perut tba-tiba mengalami nyeri terutama pada perut sebelah kanan AND otot terasa nyeri AND warna kulit menjadi ke kuningkuningan THEN Liver.

2. IF batuk terus menerus dan berdahak selama tiga pekan atau lebih AND dahak bercampur darah AND demam atau meriang lebih dari satu bulan AND berkeringat pada malam hari tanpa penyebab yang jelas AND badan lemah dan lesu AND napsu makan menurun AND berat badan mnurun THEN Thuberculosis (TBC).

3. IF kehilangan konsentrasi AND pola tidur berubah AND lebih suka berdiam diri AND kehilangan motivasi dalam menjadi hubungan dengan orang lain maupun dalam hidup secara keseluruhan AND rasa pegal pada sendi THEN Skizofrenia.

Tabel 2. Aturan untuk Solusi

\begin{tabular}{ll}
\hline No & Solusi \\
\hline \hline 1. & IF menjaga kebersihan diri dan \\
lingkungan AND rajin mengkonsumsi \\
air mineral 8-10 gelas / hari AND \\
menghindari makanan rang \\
mengandung lemak jenuh dan bahan \\
pengawet AND banyak menkonsumsi \\
Sayur dan buah THEN liver. \\
\hline IF Hindari merokok AND minum obat \\
TBC AND perbanyak konsumsi daging \\
sapi AND berbanyak mengkonsumsi \\
telur ADN minum susu secara teratu \\
AND banyak meng konsumsi buah dan \\
sayur,terutama buah jeruk THEN \\
Thuberculosis (TBC). \\
IF minum obat antipsikotik secara \\
teratur AND sering mengkonsumsi \\
kacang almond AND sering \\
mengkonsumi ikan AND sering \\
mengkonsumsi daging AND minum \\
susu secara teratur AND perbanyak \\
konsumsi sayur terutama brokoli THEN \\
Skizofrenia. .
\end{tabular}

Tahap pengujian aturan dilakukan terhadap 5 pasien dengan gejala masing-masing yang dirasakan. Hasil pengujian terhadap 5 pasien memperlihatkan bahwa aturan-aturan yang disusun mampu mengidentifikasi dini jenis penyakit yang diderita oleh setiap pasien. Tabel 
3 memperlihatkan hasil observasi terhadap 5 pasien menggunakan aturan pada Tabel 1 .

Tabel 3. Hasil Observasi Pasien Terhadap Aturan

\begin{tabular}{|c|c|c|}
\hline Id Pasien & Gelaja Dirasakan & $\begin{array}{l}\text { Jenis Penyakit } \\
\text { Teridentifikasi }\end{array}$ \\
\hline Pasien_1 & $\begin{array}{l}\text { Rasa mual yang } \\
\text { terjadi dengan } \\
\text { frekuensi yang } \\
\text { cukup sering, muka } \\
\text { pucat, otot nyeri }\end{array}$ & Liver \\
\hline Pasien_2 & $\begin{array}{lr}\text { Batuk } & \text { terus } \\
\text { menerus, dahak } \\
\text { bercampur darah, } \\
\text { badan lemah dan } \\
\text { lesu, nafsu makan } \\
\text { berkurang. }\end{array}$ & $\begin{array}{l}\text { Thuberculosis } \\
\text { (TBC). }\end{array}$ \\
\hline Pasien_3 & $\begin{array}{l}\text { Kehilangan } \\
\text { konsentrasi, lebih } \\
\text { suka berdiam diri } \\
\text {,rasa pegal pada } \\
\text { sendi, nafsu makan } \\
\text { berkurang. }\end{array}$ & Skizofrenia. \\
\hline Pasien_4 & $\begin{array}{l}\text { Pola tidur berubah, } \\
\text { lebih suka berdiam } \\
\text { diri, kehilangan } \\
\text { motivasi dalam } \\
\text { menjadi hubungan } \\
\text { dengan orang lain } \\
\text { maupun dalam } \\
\text { hidup secara } \\
\text { keseluruhan. }\end{array}$ & Skizofrenia. \\
\hline Pasien_5 & $\begin{array}{l}\text { Air kemih yang } \\
\text { berubah warna } \\
\text { menjadi seperti air } \\
\text { teh, perubahan pada } \\
\text { feses menjadi } \\
\text { pucat, perut tba-tiba } \\
\text { mengalami nyeri } \\
\text { terutama pada perut } \\
\text { sebelah kanan, otot } \\
\text { terasa nyeri, warna } \\
\text { kulit menjadi ke } \\
\text { kuning-kuningan. }\end{array}$ & Liver \\
\hline
\end{tabular}

\section{Kesimpulan}

Penggunaan Forward Chaining untuk identifikasi dini jenis penyakit pada pecandu narkoba mampu mengidentifikasi penyakit yang diderita pada pecandu. Dari kelima pasien yang dijadikan uji coba dapat ditunjukan bahwa forward chaining mampu menentukan dini jenis penyakitnya. Pada penelitian ini, keterbatasan aturan yang digunakan menjadi kendala tersendiri, karena kurangnya dokter yang memang fokus pada penanganan penyakit bagi pada pecandu narkoba. Penelitian selanjutnya dapat dikembangkan dengan mengumpulkan data-data aturan untuk basis pengetahuan yang lebih kompleks serta menggunakan teknik-teknik lain seperti teknik ketidakpastian untuk mendukung hasil akhir dari diagnosis yang dilakukan.

\section{UCAPAN TERIMAKASIH}

Ucapan terimakasih disampaikan kepada RISTEK DIKTI yang telah mendanai penelitian ini untuk skim Penelitian Dosen Pemula (PDP) tahun anggaran 2018.

\section{REFERENCES}

Achmad Wahyono, Alvino Oktaviano, Sistem Pakar Diagnosa awal Penyakit pada anak dengan metode forward chaining berbasis web, Universitas Pamulang

Arhami, Muhammad; 2005, “Konsep Dasar Sistem Pakar ; Jogjakarta: Penerbit Andi

Bekam Herbal, 2013, “ Modul Belajar Bekam Sinergi. Diambil tanggal 8 Juni 2015 dari http://www.bekamherbal.com/berita/454bekam-adalah-pengertian-bekam-definisiasosiasi-bekam-Indonesia.

Kendall\&Kendall, 2010, “ Analisa dan Perancangan Sistem”, Edisi ke-5, PT Indeks

Kusrini, 2006, " Sistem pakar Teori dan Aplikasi”, Yogyakarta, Andi Offset . Yogyakarta

Kusrini, 2008, “Apliasi Sistem Pakar", Yogyakarta, Andi Offset

Kusumadewi, S. 2003, "Artifical Intelegence ( Teknik dan aplikasi), Yogyakarta, Graha Ilmu.

Nur Ali Arrosyid (2015) "Sistem Pakar Diagnosa Penyakit Gigi Di Klinik Gigi Apotek 128",

Sri Setiyowati (2015), "Sistem Pakar Untuk Mendiagnosa Penyakit Dengan Metode Forward Chaining Untuk Pengobatan Bekam Di Klinik Tradisional Metode Herbal Dan Terapi Bekam Tarogong"

Turban, Efraim dkk (2005).Decision support system and intelegent system. Yogyakarta: Andi

Tutik Gusti Ayu Kadek, Delima Rosa, Probeyeekti Umi, 2009, Penerapan Forward Chaining pada Program Diagnosa Anak Penderita Autisme, Jurnal 
ISSN : 2406-7741

Jurnal ProTekInfo Vol 5 | September 2018

E-ISSN : 2597-6559

Informatika, Univ. Kristen Duta Wacana Yogjakarta.
Wiwi Verina, 2015, Penerapan Metode Forward Chaining untuk mendeteksi penyakit THT, Jatisi, Vo 1 No.2 Maret 2015 